\begin{abstract}
Historically, design education was structured around projects as solvable within a foreseeable and knowable future. However, researchers operating in the landscape of transition design must contend with far less certain terrain. Challenges fall outside the scope of what has commonly been understood as the designer's purview. Transition projects do not fit within the customary rhythms of political, economic, and governmental systems; they often require replete and complex coordination between actors in different systems; they are directed towards social, cultural, and psychological change; the location of practice is a living system that offers no reliable set of inflection points. Considering practice-based transition design research, this article outlines approaches taken, discusses challenges of conducting research, and proposes key considerations to address in future work.
\end{abstract}

Key words: Transition Design - futures - practice-based research - alternative economics.

[Abstracts in spanish and portuguese at pages 281-282]

${ }^{(*)}$ Michael Arnold Mages is a researcher and $\mathrm{PhD}$ candidate at Carnegie Mellon University. He also runs a design consultancy specializing in strategically oriented design practice: research, communications analysis, and planning, and is a partner in a startup that helps organizations have difficult conversations facilitated using deliberative democracy practices. Clients include mid-sized regionally oriented businesses, startups, universities, and Fortune 100 companies. Michael has taught research informed design practice to students in business, computer science, and fine arts at the University of Colorado, The University of Denver, and now, Carnegie Mellon University. Michael's research includes designing for high-stakes and difficult conversations, sustainability, and designing for experience. michaelam@cmu.edu

${ }^{(* *)}$ Dimeji Onafuwa is a researcher and Ph.D. candidate at Carnegie Mellon University. His work seeks to understand the impact of platforms on contributing to the commons. A practicebased interpretation is how Ostrom's design principles might serve as a basis for user experience on platforms. Dimeji's work on a research project exploring multi-stakeholder interactions around tenant/landlord decision-making led to his work on tenancy as a contribution to the commons. Recently, he has begun investigating the emergence of patterns from commoning acts. Before joining CMU, Dimeji ran a design studio for eight years. He currently works as a UX consultant and serves on local government and corporate boards.dimeji@cmu.edu 


\section{The Point of Departure}

At the time of this writing, transition design research is a relatively new practice. Drawing from a host of transdisciplinary approaches, transition design's central goal is design-led, societal, or systems-level transformation towards more sustainable futures -a transdisciplinary approach for seeding and catalzying systems-level change and societal transitions (Irwin, Kossoff \& Tonkinwise, 2015). Within the context of the authors' research, specific design projects within a transition design framework have taken many forms: designing objects that evoke specific behaviors, designing interactions that encourage the adoption of social practices, and designing new ways of organizing human activity. A framework for transition, proposed by Kossoff (2011), requires designing frameworks for transdisciplinary collaboration as an essential feature of any model of transition practice. A key aspect of that transdisciplinary collaboration is moving the locus of control for those practices away from remote governance couched in multinational corporations or technocratic, federated systems and towards systems that are organized and administrated locally, that can be evaluated by, and are directly accountable to, the people and natural systems that are affected by practices. Further, transition design is an approach to designing that grows fundamentally out of socialist, or anti-capitalist, economic systems (Irwin, 2015), viewing an extractive industrial economy as an essentially outmoded form and globalized capitalism as both a morally and fiscally bankrupt ideology.

The authors of this article have been engaged over the past four years in practice-based research, exploring processes of designing for collaboration and designing with collaborators. It is from this standpoint that we have developed two approaches for transdisciplinary collaboration: designing for deliberative conversation, and recommoning as approaches toward local, symmetrical conversations, negotiations, or collaborations between actors. In the course of this work, we have engaged in exploratory work with groups of stakeholders at different levels of systems, attempted new ways of practicing design, and developed approaches that are collaborative, that challenge the definitions of expertise, and that encourage people to assume agency in processes that are complex, difficult, and fraught. We have examined opportunities for helping people assume responsibility for their own systems, and helping people interface more effectively with government and other systemic actors that influence their lives and livelihood.

As researchers educated in design practice, coming to this point is made more challenging. As the site for transition designing is built upon the foundation of designing, where design (aside from some notable exceptions as the computer-supported cooperative work movement) has served (and continues to serve) as the accomplice of commercial economy. Professional practice, design research, and design education have evolved principally to serve the end of selling goods to people.

Because of how design education has been structured and how professional design practice has framed projects and approaches to problems, design researchers approaching researching transition practices and practitioners aspiring to engage in transition designing must strive to unset attitudes, beliefs, values, postures, and mindset (Irwin et al., 2015) that are a thoroughgoing presence in the greater discipline of design. Specifically, design researchers adopting a transition mindset must contend with challenges that, historically, 
have fallen outside the purview of design. Namely, working in a mode where design acts fall outside of the scope of the customary rhythms of political, economic, and governmental systems; design acts require replete and complex coordination between actors in different systems; and design acts are directed towards social, cultural, and psychological (cognitive?) change, that is, beliefs, attitudes, and mindset. The argument that transition design is inherently local, or place-based, presupposes a design practice located in a particular living system -and living systems offer varied, anomalous intervention points. Therefore, research in transition design is confronted with particular challenges.

This article will detail some of the key challenges to conducting research in a transition design paradigm and will articulate some approaches to conducting work in this space.

\section{How Designers are Trained to Think...}

\section{...And the Problem of Personas}

A single chapter in Alan Cooper's The Inmates are Running the Asylum (1999) delineated an approach to design that moved a singular fictional user's experience to the center of evaluative considerations, supplanting technical concerns, business concerns, sales goals, and the designer's aesthetic. This intervention was a key point in the movement away from modernist concerns of simplicity and artistic representation (Itten, 1975) and towards the privileging of use-value as the essential way to understand the designed object (Cooper, 2008). In this subtle yet supremely powerful political move, Alan Cooper redirected the efforts of the design discipline, and the businesses designers advise, over the last score of years. Following a path begun by Donald Norman in his book The Design of Everyday Things (1988), Cooper and his accomplice, Jakob Nielsen, through his long-lived blog useit.com and Designing Web Usability (2000), also divert design towards addressing usability and human needs as the principal end and goal of design activity.

Still a prevalent approach in design practice and education (Kujik \& Staats 2012), designing with personas establishes a set of relations of enablement and constraint (Schatzki 2002). This practice of designing focuses attention on fictional archetypal individuals, which may reflect the hegemony of the current culture more than what could or should be part of a future community.

Designing based upon personas reinforces the hegemony of the individual. In the fictional world of scenarios, critical paths, and use-cases created for product design, the persona takes on heroic proportions and valorizes the worst aspects of prioritizing needs. Structuring a design through personas bakes privilege into the system.

Though placing the human at the center has philosophical antecedents in humanism and the civil rights movement and purports to orient attention towards the dignity of the human as a vital part of an interaction that was once technologically centered, we have, with our personas, made the wrong turn at Albuquerque. The use of personas in design practice ensures that instead of designing for heterogeneity, we design for a singularity. Designing with personas neglects the relational character of designing in contemporary, complex systems. Considering contemporary problems through the lens of the wicked problem of Rittel and Webber (1973), approaches to complex, multilayered challenges 
that plague designers are, in essence, problems of relation and must be approached principally through facilitation (Conklin, 2006; Sanders \& Stappers, 2014) and improvisation (Goodman, Stolterman, \& Wakkary, 2011; Paquet, 2013 citing Weick, 2004).

\section{...And the Problem with Solutions}

The clichéd rhetoric of the problem/solution (IDEO, 2011) is as thoroughly embedded in the design discourse (Willis, 2015) as the use of the Post-it Note, or sketchbook. Framing design problems as solvable, and aspects of the problem as scientifically knowable, leads students down the perilous path to solutionism, where the challenges of the work are subsumed by the impractical effort to "solve" the problem.

To attain a position from which design might approach problems, rather than "create solutions" and "design our way out of it", designers need to focus on engagement with a network of stakeholders to collaboratively define the problem that is faced by the community, fuse collaborative coalitions from disparate groups, and coordinate subsequent efforts operating from various perspectives. Yet, much of design's education and professional practice remains oriented around the problem/solution dichotomy.

\section{Design's Way of Knowing is Through Making}

In order to approach problems, a requisite variety (Ashby, 1957) is necessary in the set of approaches to those problems. Speaking in generalities, the key way of knowing through design is knowing through making (Tonkinwise, 2008). Yet the making that is transition challenges designers to go beyond the scope of the thing-making that has preoccupied so much of design education. Transition approaches extend to service-making, systemmaking, community-making, world-making -activities that are little approached in the typical design curriculum.

\section{Short Term-ism}

Many transition projects must work outside of time scopes where projects exist in the commercial sense. Transition projects like Cheryl Dahle's Future of Fish may take 10 or 20 years to accomplish. Reconsolidating democracy and encouraging public participation in a governmental system that citizens view as broken is a challenging and long-term endeavor. Transition projects, unfortunately, don't fit well within the four- or even seven-year scope of a doctoral investigation. These types of projects also require long-term commitments from partner organizations and may require gaining the trust of different communities and community stakeholders across multiple levels of government, the nonprofit sector, and other community actors.

These long-term transition-oriented projects also fall outside of funding schemes of a capitalist system. The structures of annual reporting and the pressure to show results within a one-year timeframe make securing funding and the long-term commitment necessary to implement a transition project an extraordinary leap of faith. 
Design educators have not been trained to think with a view towards designing transition. Designing in a long-term arc where visible markers of success may be deferred for months or years is not something that is part of education or professional practice. As yet, design has not developed a view that incorporates understanding shorter-term markers as indicative of longer-term success. Understanding and learning to focus on even a year-long project is not a skill that submits well to partitioning into month-long project sections that are contained within a 16-week semester. A typical professional design project has a scope of only three to six months and may be seasonally executed. A transition project might involve ebbs and flows of work over a period of years, retracing the same steps of introduction with each new stakeholder.

Many designers enter the workforce with the training and education provided by a Bachelor's degree in design or a related field. In spite of calls for nearly a decade to integrate systems thinking (AIGA, 2008; Davis, 2008) as a component of the approach to designing in education and professional practice, many undergraduate programs remain focused on the craft of design. In a typical four-year design program that is based on the semester system, within the 120 credits that comprise the BFA Design degree, $40-48$ credits comprise the education in the major, with approximately one-half to two-thirds of that (24-32 credits) reserved for studio courses in the major. While this infuses students with essential basics -an understanding of the fundamental principles of design, approaches to formalism, an operational understanding of semiotics as applied to type, color and image- courses that operate outside of these boundaries are considered a luxury. Faculty continue to be evaluated as artists, discouraging a research culture within universities (Davis, 2016). Even design history courses are not extant uniformly across academic programs in the discipline, nor is the existence of courses to teach the important extra-formal skills of design (research, project planning, asset sourcing, collaboration, etc.). These skills are left to be folded into the studio and presented in an ad-hoc way as they occur throughout the students' work process.

After making the transition to professional practice, former students adopt the rhythms and practices of their new environments and bring with them skills that fit within their corporate contexts and the narrow scope of an entry-level designer's job responsibilities. Training for thinking strategically, planning in long-term arcs, and confidently designing while deferring the rewards of performance markers is not reinforced as part of the onthe-job training of professional practice. Paradoxically, the least experienced person in a corporate setting may have the most up-to-date skill set and be the most able to speak to the challenges particular to transition designing. Yet that person may be shunted towards craft-centered production work, where their knowledge goes untapped.

In professional practice, designers have a wealth of digital metrics to examine the efficacy of their work. A || B testing, sales metrics, application-use heatmaps, and user testing all provide immediate and actionable feedback that designers can use to evaluate the effectiveness of their work. Sidestepping for now whether this is an effective way of designing, or whether data-driven epistemologies can comment on how a designed object functions in a given culture, these metrics are part of a tight loop of use $=>$ measure $=>$ edit that typifies contemporary design approaches. In point of fact, the design-related discipline of human-computer interface design (HCI) is structured around these tight feedback loops 
that generate information to streamline and optimize the production of an existing product or service.

Yet, it is not optimization that we need at this particular historical moment, when the center of understanding commerce and approaches that design might make as the handmaid of commerce is oriented towards data-driven optimization. Developing a suite of effective tools for smoothing rough edges off of applications, products, and services is not what transition design aims to produce. Rigorous tools that have been developed for knowledge production in HCI or design-based user testing can be ineffectual or even counterproductive when applied in a transition design context.

The goal for transition design research is both the unmaking of the existing order and reorienting the mangle of socio-technical systems and renegotiating their relationship with the so-called natural systems upon which they survive, like bacteria upon agar. While this may seem like the fever dreams of post-Marxist post-capitalist academics of the Anthropocene, there are real steps that a research practice in transition design can take to generate change in the current suite of approaches.

By and large, publicly traded companies' economic systems are organized around quarterly and annual reports. Sales, product development, research, and development are pressured to show value creation within 3- or 12-month time cycles (Laverty, 1996). That reporting cycle and its association with the perceived valuation of the work a company has produced over the last few months drives a kind cautiousness, an incrementalism in approach that focuses on short-term gains over riskier paradigm-shifting projects.

There are two important forces are at play in the design of products and services: innovation and optimization. Innovation (or if you prefer the currently vogueish term, disruption) approaches the problem field from the point of developing a novel approach, whereas optimization can only operate when there is an existing approach already at play. Innovating where a novel approach is introduced into a system is exceedingly rare. Once an initial approach is in place, organizations tend towards optimizing behavior.

The vast amount of business moves are optimizing, or "build a better mousetrap", moves. In the mousetrap scenario, the problem field is an area where undesirable rodents are living. At the conceptual level, virtually no innovation has occurred in the field of mousetraps since the device's invention. The central act is trapping or killing rodents with a device that must be set by a human and serviced by a human. The relation that the human has with this device has mostly remained unchanged. Innovation in this space might be represented by an approach that makes the entire house inhospitable to mice, or perhaps devices that attract more mice to live in the house to forward some end for the human residents of the house.

Transition design, with its particular focus on systemic problems and their manifestation in local systems, cannot presume the current system of capitalist-based extractive economy as tenable and instead proposes reorienting systems of production and supply towards local economies. It follows that this approach addresses designing for changes in scale, ownership, and material, as well as rethinking the set of systems that produced the unsustainable structures in the first place.

One might hope that political systems, with two-, four-, and six-year election cycles, might be the site for transition research, that elected officials might better understand the need 
for the redevelopment of a community's physical and psychographic infrastructure, but within those systems, there is significant pressure to preserve the status quo and to focus on incremental steps that read favorably in news cycles and can be pointed to as a demonstration of policymaking success.

\section{Challenging Paradigms with Sustainable Alternatives}

A research practice in transition design looks beyond existing conditions to alternatives that might challenge what we perceive to be the norm. In Take Back the Economy, Julie Graham and Katherine Gibson, under the moniker J.K. Gibson-Graham, draw our attention to different activities that reside under the surface of this capitalist-driven economy. These activities exist beneath what they call "the iceberg economy," and they are very diverse more diverse than we assume. These activities are also interconnected in ways that cannot be easily described within the current capitalist frames. Some of them include bartering systems, producer and consumer cooperatives, local unions, small collectives, produsages, transactions between friends, and different forms of unpaid labor, to name a few (GibsonGraham, 2013, pp. 10-11). They point to the disproportionality with which we ascribe value to labor. And they show us how unsustainable our more visible everyday practices are. When labor is uncategorizable under the current system, there's a tendency to believe that it does not exist. However, what is unsustainable is the mass production of goods perpetuated by the effects of the Industrialization Era. The expansion during this era enabled manufacturers to continue to introduce new products to an ever wider audience. However, this unfettered appetite for growth has led us to an over-reliance on otherwise limited resources. Economies predicated upon the extraction and consumption of what was once thought to be unlimited resources has also increased our appetite for products at all cost without regard to the origins of the material resources, leading to large-scale global problems. We have reached the age in which our consumption has a direct effect on the livelihood of others. This unfettered growth has also led to an expansion of the wealth gap -between "rich" and "poor" countries, as well as "rich" and "poor" households. Most importantly, it is leading us on a course from which we may never return. Most of what we think is unlimited economic growth may be waste, as the systemic problems we face are interconnected. Unmitigated economic growth affects our natural environment as well as our collective wellbeing (Capra \& Luisi, 2014, pp. 362-363). Tony Fry calls this societal failure "defuturing," and a course correction is needed, what he calls "redirective practice" (Fry, 2007, pp. 5-7) Fry's call for redirective practice reminds us to reconsider our preoccupation with productivism at the expense of our collective futures. Research in transition design causes us to look at other modes of living together and find new ways of organizing human activity.

\section{New Ways of Organizing Human Activity}

Discovering new ways of organizing human activity begins with rethinking how we share resources essential to our collective survival and exploring new (local and embedded) 
techniques for sharing. One such resource is housing. In recent years, a cultural shift has led to access to shelter becoming a byproduct of neoliberal policies and global capitalist development. These policies have favored profit maximization over social responsibility and have left many social practices we have built around sharing housing on the wayside. An intervention point for transition designers is to re-prioritize housing and what "living together" means.

\section{Deliberative Engagements: Top-Down}

Decreased perception of the importance of a democratically elected government has created a moment of crisis for proponents of liberal democracy (Foa \& Mounk, 2016). The recent rise of factually impoverished, emotionally overabundant political discourse in recent elections in the United Kingdom and the United States has continued to infect the discourse of several major governments in Europe and the Americas. In spite of this concern-worthy recent history, when examining discourse at the level of the individual, civic engagement events have shown that citizens can be trusted to discuss issues, share motivations, and come to conclusions (Fishkin \& Luskin, 2005).

One of the authors of this paper, Michael, is engaged in research exploring the influence of a system of stakeholders and the power of material interventions in facilitating deliberative conversation. This work views the civic conversation as a key precursor to civic change and successful civic change as requiring engagement across a complex network of actors. A civic conversation is a key place for knowledge transfer, a moment where citizens are able to come to an understanding of the needs of the greater community, and a moment where they can articulate the challenges faced by their communities and the needs that these challenges entail. Citizens have the opportunity to hear the needs of their neighbors and perhaps place their own needs in the context of a portfolio of need across the entire community. The moment of the civic conversation is where government actors have the opportunity to collate critical information to guide policymaking and to develop a better understanding of the needs of the communities they serve. This understanding serves as a framework or heuristic to guide the creation and application of policy.

Affordable Housing Task Force. An example of the work is with the City of Pittsburgh's Affordable Housing Task Force (AHTF), which convened citizens to determine where areas of greatest housing need were within the city, and what solutions citizens wanted to see in their neighborhoods. Participants in the AHTF included city council members and representatives from 22 area businesses and not-for-profit organizations.

The city council convened the Affordable Housing Task Force, which was responsible for providing legislative and budgetary recommendations to the city council, which would ultimately structure the city's policy approach.

The perverse thing is, in these situations where there is a lot at stake for individuals, and many perceived levels where the distribution of responsibility between the levels and the potential for influence at each level is not well understood, stakeholders often attempt to exert influence at every level and at every step in the process. Some business groups and 
community groups chose to eschew the public comment process entirely, instead attempting to influence city council members directly.

Protest groups with various political goals came to the public meetings in an attempt to make their presence felt in different ways. Some handed out flyers, some brought signs, some requested that they be allowed to watch the process. One group identified the exit survey as a vulnerable point for intervention and created stickers that residents could put on the survey instead of writing a personal narrative. Another group protested the choice of meeting locations, alleging (correctly) that there wasn't a meeting in a particular neighborhood hit hard by the recent fluctuations in the real estate market. Another group insisted that any notes that were taken by city employees at the meetings be published on the city's website. One key observation is that protesters are not an enemy to the process, as they contribute to the diversity of the conversation (Young, 2003).

The protocol asked attendees to evaluate the city's proposed housing priorities and values in relation to attendee's own needs and the needs of their neighborhoods. And despite (or perhaps because of) all the above, this was generally successful in producing unambiguous priorities for the Affordable Housing Task Force. In relation to other priorities: housing rehabilitation and home ownership emerged as key factors from the discussion. The rich network of interrelationships in a city, the variety of processes at work, diversity of people, and non-human actors, and the nested networks, or systems-within-systems nature, of cities make them fertile grounds for frameworks for participation and governance that tolerate rational applications within those frames. Deliberative democracy procedures can act as both a filtering and focusing element in civic conversations by bounding the problem at hand, providing relevant information to participants, and creating structures through which that feedback can be processed so that it can be effectively consumed by governmental entities.

However, deliberative democracy as an engagement that is only sponsored, in a top-down method, is perhaps not sufficient to catalyze social change on the grand scale that is referenced in writings of potential apocalyptic futures. Opportunities for designing conversations need to step outside the mode of facilitating the statutory requirements of municipal government and architectural firms doing public works. Designing engagement processes with a systems-level view of the network that is organized around seemingly intractable issues, and activating that network so that tangible outcomes can be produced, is a central project for transition design.

\section{Negotiating Resource Sharing: Bottom-Up}

In much of the United States, access to housing has increasingly become more difficult, especially because wages have failed to track with the steady increase in rental prices. In Portland, Oregon, for example, rents have seen over $10 \%$ annualized growth in the past year (compared to a U.S. average of $4 \%$ ) while wages have only increased by about $4 \%$ (Hammill, 2016). These problems are not unique to Portland -they are global. A recent United Nations report on housing details a massive shift of global investments that are leaving homes empty even while many people remain homeless, because of increasing of enclosure tactics and privatization of property, which makes housing even more inacces- 
sible. Housing is no longer valued based on the social benefits to communities. Instead, they are valued based on profitability, which is often prioritized over social good, leading to what Michael Heller calls the tragedy of the anticommons (1998). The anticommons property theory mirrors the commons property theory. In a commons, multiple stewards are granted the privilege to access and use a resource. Their right to access might lead to overuse and eventual depletion and scarcity. The inverse happens with the anticommons, that is, when we have multiple owners who are endowed to exclude others from use of a scarce resource, the exclusionary tactics lead to underuse even in light of desperate need. An example showing the emergence of this tragedy is the city of Melbourne, Australia, which has over 80,000 properties. Yet many residents, find it tough to access housing. This problem is fueling racial and social inequalities that are hard to surmount (Foster, 2017). Large and mid-sized cities in the United States are facing similar tragedies, including New York City, Charlotte, North Carolina, Los Angeles, California, Pittsburgh, Pennsylvania, and Portland, Oregon. The effects of rent increases and housing inaccessibility are by and large affecting communities. They are spiking rates of homelessness, reducing safety and leading to underperforming schools.

Portland Tenants United. Dimeji, the other author of this paper, works with Portland Tenants United (PTU) in the city of Portland. PTU is a local collective comprising tenants and a few landlords agitating for policy changes regarding housing, as well as attempting to redefine the relationship between landlords and tenants by creating better mechanisms for negotiation. They aim to intervene at different levels of the problem. PTU forces the issue that housing is a fundamental human right, something that we all need to survive, by mobilizing tenants to build a counter-power to the "landlord lobby."

PTU has enjoyed a few recent successes, one of which is an amendment to what is called the Relocation Ordinance (Ordinance 188219), which was passed on February 3, 2017, to provide protections for tenants facing no-cause evictions. The amendment added a clause that mandated relocation assistance when these tenants are involuntarily displaced (Portland Auditor's Office, 2017). While modest, these additions to the law are quickly becoming a legislative template for other laws in Washington State as well as other parts of Oregon. However, PTU members are well aware that these laws, while they are modest gains, need to be ratified and made permanent. Through a series of transition design workshops, they are looking at different ways of converting these temporary laws into permanent cultural shifts. For example, they are investigating ways to reward positively deviant landlords with "tenant-approved" seals that indicate their commitments to tenant rights.

Bringing a unique posture to these types of social problems is essential to research practice in transition design. The altered posture of a transition design researcher comes from a place of realizing that the designer is not always "central" to the project and may instead play a critical role as facilitator, convener, or catalyst. The community itself brings a level of expertise that is not available to the designer (Fischer, 2000). There are also cultural nuances that should be accounted for that reside outside of the designer's purview. This particular example of work with PTU has members actively engaging in local politics. They know a lot about the policy positions of various members of city council. Members are also familiar with motivating members of city council, using a combination of public 
shaming and negotiation tactics to get those members to the table so public action groups can attempt to sway their opinion.

\section{Innovating in Pre-collapse}

Transition design practice leads to innovation that helps a failing system avert collapse. Such system innovation, when adequately incubated, may allow for changes to be made at different points of inflection. The potential for a system to avert collapse is often enhanced either through socio-technical interventions or through learned indigenous behaviors that reduce intractability. If successful, these interventions create discontinuities with the status quo by presenting radically "new" alternatives.

\section{Creating Alliances: Outside-In}

Future of Fish. Future of Fish supports change at all levels in the sustainable seafood industry through convening stakeholders to co-design systems-level interventions. As the former Future of Fish CEO Cheryl Dahle shared in an interview, "the platform" for these interventions is comprised of the people that participate in different aspects of the seafood supply chain -from the individual fishers to distributors, restaurateurs, and chefs. Participants are invited to co-design sessions to convene where the end goal is creativity, not consensus. Dahle argues that driving consensus is not the priority of the workshops. Instead, the focus is on the power of design to shift the discussion from overall individual successes to that of agreement on next moves. Participants start the process with disagreements, do enough research to see where their interests align, and come to the realization that these alignments could serve as entry points to further conversations. With guidance from facilitators, the idea-generation process is built on authenticity and creative energy. Like the broad-based issues that affect cities, Dahle and her team believe that seafood sustainability is a systemic problem. An extractive, capitalist mindset results in practices that are quickly depleting our oceanic resources and that foster a system that is unable to trace the seafood from catch to plate with any degree of accuracy. As a result, the system needs intervention. Dahle is convinced that when participants in the system hear stories of the daily struggles others within the system are facing, and consider those stories in light of their own practices and situated expertise, they will make better decisions, and these decisions will be meaningful for the overall system.

In light of innovations that improve feedback within the system, only a small percentage of bad actors will continue to be motivated by monetary incentives to act illegally by falsely labeling fish. According to Dahle, this group is only about $10 \%-15 \%$ of the total population, and they will be offset by individuals that require no incentive to do the right thing. A larger middle tier consists of those who opportunistically shift back and forth between acting appropriately and cheating the system. This segment is ripe for design intervention and is consequently the focus of most of Future of Fish's effort. As Dahle states, "If you can prove to people that the upside of technology is financially better than the upside of fraud, 
then they will want to contribute". Doing this requires integrating technology, providing correct data, and telling the story of sustainable seafood as not only good for the environment but also as providing better value. It is data and amplification that get you to the tipping point that causes a systemic shift. "A few years from now, data and fish are going to be paired with no room for bad actors", Cheryl Dahle believes.

Transition design encompasses big-picture thinking, multi-phase, multi-level, and multipattern interventions. Additionally, this practice requires seeing smaller-scale implications within seemingly intractable problem spaces. Transition designers such as Cheryl Dahle understand the patterns (from human, ecological, and socio-technical systems), identify levers for collaboration, in this case, within the seafood systems, and see how these might be translatable to human behavior.

\section{Learning from Indigenous Practices: Inside-Out}

Makoko fishing settlement. A resilient community has strong local networks and governing mechanisms. The settlement of Makoko in southwestern Nigeria embodies these characteristics. Makoko is a floating settlement, a city built on stilts on the Lagos lagoon. Established in the 19th century by the Egun and other tribes who migrated from Badagry, Benin, and Togo, present-day Makoko comprises six distinct villages: Adogbo, Apollo, Agbon, Migbewhe, Oko, Sogunro, and Yanshiwhe. It is the world's largest floating city, with almost 100,000 residents. As Lagos state government efforts to demolish the settlements have failed, Makoko villagers find themselves pushed further into the waterways where they have established residence. Nowadays, Makoko is a self-sustaining community independent of the government. They have their own local government and schools. The city has developed local governance and resource-sharing mechanisms to ensure residents' collective survival. For example, Makoko boasts one of the lowest crime rates in Lagos because of their self-policing systems. Yet, Makoko is faced with significant challenges. In particular, residents depend on the water for their livelihood, but the water is increasingly contaminated, and residents are facing risks of exposure to water-borne diseases such as typhoid and cholera (Ogunlesi, 2016).

One of the reasons Makoko residents are facing displacement is that the areas around the settlements are high-income communities built on reclaimed land. Makoko is also highly visible from a nearby major bridge -the Third Mainland Bridge- a gateway access into the greater Lagos area (Ajayi, et al., 2014). These communities are also experiencing the adverse effects of climate change. Homes in Lekki and Victoria Island often flood, and many streets are frequently waterlogged and impassable. However, many Makoko residents have adopted strategies for dealing with permanent flooding. For one, their houses are built on stilts using a combination of wood, metals, and found objects that are mostly resistant to rising water levels. Also, Makoko is, in effect, a future city, as the increasing saturation of land mass, as well as climate change and rising sea levels, will lead us to envision alternatives for building coastal settlements. We only need to look at cities such as New Orleans, Louisiana, as well as the Florida Keys, to conclude that coastal settlements are precarious, that variable water levels are a concern. Makoko is a foretelling of that new 
reality for coastal communities. Considering the challenges Makoko residents are facing, we are beginning to see in old, indigenous communities new configurations of human life in a contemporary context -emergent strategies for collaboration and social organization, innovative approaches to deliver infrastructural needs, and residents working with the immediate environment to ensure survival.

\section{Implications for Transition Design Research and Practice}

\section{Changing Culture}

Much of transition design is about changing culture. But cultural change is slow, and it takes time. Transition design research refigures the culture of design research and design practice itself. Design practice has always been short-term, assumed resource extraction from a closed system, and preoccupied with artifact, materials, and products. Transition design projects have much longer lifespans, and they are not merely solutions-oriented, as many of the problems they attempt to address are "unsolvable" by their nature (Tonkinwise, 2015). Transition designers are aware of this predicament and are comfortable with modest interventions and hope that when these interventions are networked, they may eventually cause the system to shift. Ezio Manzini (2015) states, "In transition, we need to experiment with new solutions, then consolidate and replicate the best ones. These must then be connected so that multiplicity of small initiatives may make great impact". (p. 5) According to Richard Buchanan, culture is what is happening in practices. He defines culture as a verb -regarding what it does as opposed to what it is. "Culturing" is something that is always occurring: "Culture is not a state, expressed in an ideology or a body of doctrines. It is an activity. Culture is the activity of ordering, disordering and reordering in the search for understanding and for values which guide action”. (Buchanan, 1998, p. 10) Much like with culture, we are always transitioning. Our societies are always shifting. What is particularly difficult about this is that transition designers are working within the same culture they are attempting to change. This, however, is the messiness of design research. We have to be able to step outside of the problem and analyze the consequences of system disruptions and step back in to intervene. What this means is designers are bringing in the culture of design itself to address transition-related problems.

\section{Working with Others}

The messiness of transition design research (and much of design research) means that researchers must always be aware of their limitations. Researchers work within transdisciplinary contexts to reveal underlying community values, beliefs, and attitudes and analyze problems to reveal intervention points. They rely on skillsets from a broad array of disciplines, including anthropology, history, psychology, literature, and design. They are comfortable with not being at the center of every project. When the expertise for addressing large-scale systemic problems is distributed, they focus and leverage the combined expertise to foreground more effective ways to intervene. 

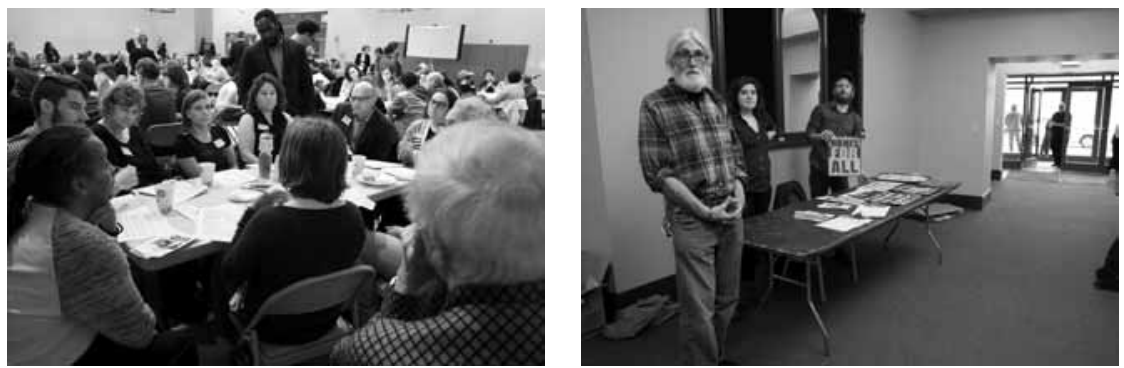

Figure 1.

Figure 2.
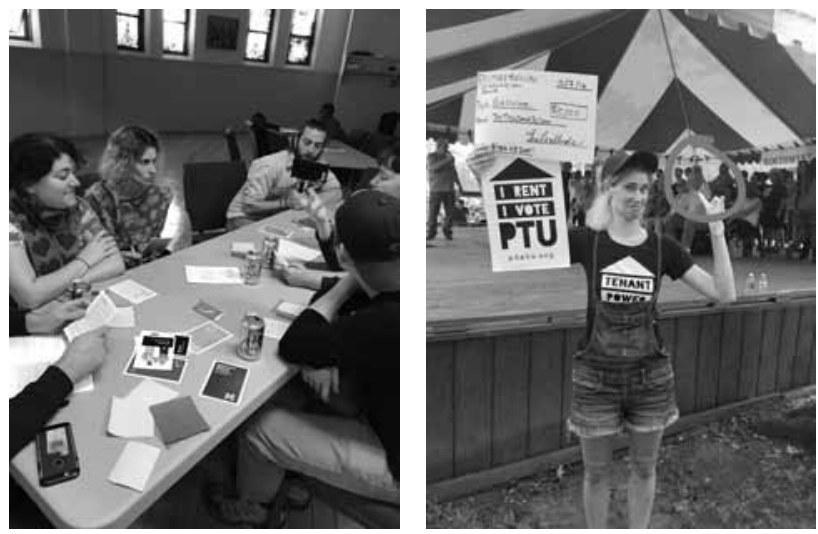

Figure 3a.

Figure 3b.
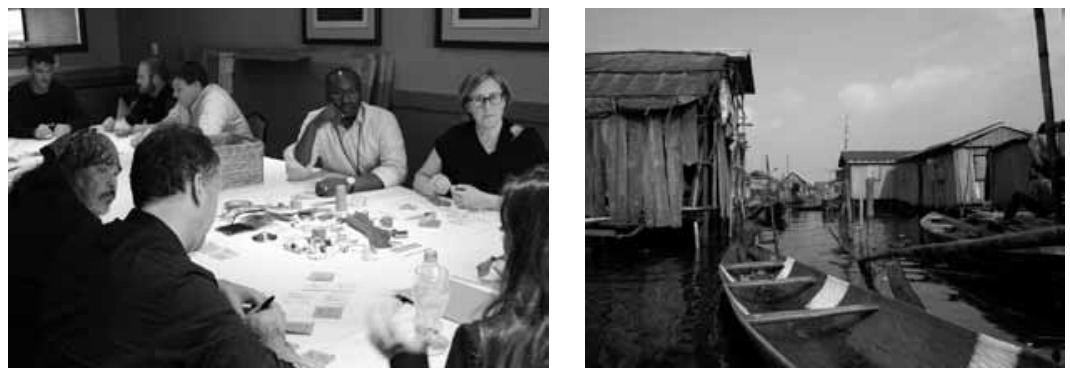

Figure 4.

Figure 5.

Figure 1. Pittsburgh residents at the Kingsley Community Center (2015) deliberatively discuss options for affordable housing in the city. Photo courtesy the City of Pittsburgh. Figure 2. Protesters from Pittsburgh Human Rights City Alliance, a Pittsburgh-based community group at the Affordable Housing Task Force Deliberative Community Forum on North Side, 2015. Photo courtesy the City of Pittsburgh. Figure 3. Portland Tenants United using a combination of shaming (3a) and negotiation (3b) using "recommoning" tools to force changes in rental housing laws. Photo credits: Dimeji Onafuwa and Margot Black. Figure 4. Future of Fish co-design session on seafood traceability. Photo courtesy: Future of Fish. Figure 5. Makoko. Photo by Heinrich-Böll-Stiftung. Licensed under the Creative Commons Attribution-Share Alike 2.0 Generic license. 
"Transition designers should also consider local perspectives, and they incorporate ideas across worldviews and generations. They also engage non-experts in the design process by relying on the unique perspectives they bring to the problem". (Manzini, 2015, p. 37) They also consider evolutionary frameworks by looking for patterns of replication in systems. From an anthropological perspective, transition designers understand that humans co-exist with and live within social systems. Knowing how communities share knowledge, resources, practices, and beliefs helps us better predict what experiences might benefit other communities.

Instead of thinking of the solution to most design problems as merely cognitive (satisficing as the most optimal solution), transition designers seek a broader path that includes understanding and documenting the dynamic system in which the problem resides. They are more preoccupied with understanding the potential approaches and determining the best point of intervention than prescribing short-term solutions that may eventually have more dire consequences.

Ultimately, transition design must take on design as the object of its own practice. As an aspect of the turn to a sustainable future, design practice and education must resign not only the centrality of their position in creative practice but also give up the centrality of approaches and rhetoric that have become the mainstay for structuring design action. In return, these approaches can be replaced with a more collaborative and deliberative practice, more aware of the social and political dimensions within which it operates.

\section{References}

Ajayi, O. O., Oviasogie, F. O., Azuh, D. E., \& Duruji, M. M. (2014). Urban design and sustainable development: a case of Makoko area of Lagos State, Nigeria. European Scientific Journal, 2 SE, 105-109.

Alexander, C. (1964). Notes on the synthesis of form (Vol. 5, pp. 46-55). Cambridge, MA: Harvard University Press.

American Institute of Graphic Arts. (2008). Designer of 2015 competencies recommendations.

Ashby, W. R. (1957). An introduction to cybernetics (2nd ed.). London: Chapman \& Hall Ltd. doi:10.2307/3006723

Buchanan, R. (1998). Branzi's dilemma: Design in contemporary culture. Design Issues, 14(1), 3-20.

Capra, F. \& Luisi, P. (2016). The systems view of life: A unifying vision. Cambridge, UK: Cambridge University Press.

Conklin, J. (2006). Dialog mapping. New York, NY: John Wiley \& Sons.

Cooper, A. (1999). The inmates are running the asylum: Why high tech products drive us crazy and how to restore the sanity (1st ed.). Indianapolis, IN: Sams-Pearson Education.

Cooper, A. (2008). The origin of personas. Retrieved from https://www.cooper.com/journal /2008/05/the_origin_of_personas

Davis, M. (2008). Why do we need doctoral study in design? International Journal of Design, 2(3), 71-79. 
Davis, M. (2016). Tenure and design research: A disappointingly familiar discussion. Design and Culture, 8(1), 123-131. doi:10.1080/17547075.2016.1142349

Fishkin, J. S., \& Luskin, R. C. (2005). Experimenting with a democratic ideal: Deliberative polling and public opinion. Acta Politica, 40(3), 284-298. doi:10.1057/palgrave.ap.5500121

Fry, T. (2007). Redirective practice: An elaboration. Design Philosophy Papers, 5(1), 5-20.

Gibson-Graham, J. K., Cameron, J., \& Healy, S. (2013). Take back the economy: An ethical guide for transforming our communities. Minneapolis, MN: University of Minnesota Press.

Goodman, E., Stolterman, E., \& Wakkary, R. (2011). Understanding interaction design practices. Proceedings of the 2011 Annual Conference on Human Factors in Computing Systems - CHI '11, 1061. doi:10.1145/1978942.1979100

Fischer, G. (2000). Social creativity, symmetry of ignorance and meta-design. International Journal of Knowledge-Based Systems, 13(7-8), 527-537.

Foa, R. S., \& Mounk, Y. (2016). The danger of deconsolidation: The democratic disconnect. Journal of Democracy, 27(3), 5. doi:10.1353/jod.2016.0049

Foster, D. (2017, February 28). UN report lays bare the waste of treating homes as commodities. The Guardian. Retrieved from http://www.theguardian.com

Hammill, L. (2016, April 26). New report: Rents rose 13 percent annually, but new supply slowed price growth. The Oregonian. Retrieved from http://www.oregonlive.com

Heller, M. A. (1998). The tragedy of the anticommons: Property in the transition from Marx to markets. Harvard Law Review, 111(3) 621-688.

IDEO. (2011). Human centered design toolkit. doi:9780984645701

Irwin, T. (2015). Transition design: A proposal for a new area of design practice, study, and research. Design and Culture, 7(2), 229-246.

Irwin, T., Kossoff, G., \& Tonkinwise, C. (2015). Transition design provocation. Design Philosophy Papers, 13(1), 3-11.

Itten, J. (1975). Design and form: The basic course at the Bauhaus and later (Revised ed.). New York, NY: John Wiley \& Sons.

Kossoff, G. (2011). Holism and the reconstitution of everyday life: A framework for transition to a sustainable society. In S. Harding (Ed.), Grow small, think beautiful: Ideas for a sustainable world from Schumacher College (pp. 122-142). Edinburgh: Floris Books.

Kuijk, J. van, \& Staats, R. (Eds.). (2012). Design for usability: Methods \& tools - A practitioner's guide.

Laverty, K. J. (1996). Economic "short-termism": The debate, the unresolved issues, and the implications for management practice and research. Academy of Management Review, 21(3), 825-860. doi:10.5465/AMR.1996.9702100316

Manzini, E., \& Coad, R. (2015). Design, when everybody designs: An introduction to design for social innovation. Cambridge, MA: MIT press.

Nielsen, J. (2000). Designing web usability. Indianapolis, IN: New Riders.

Norman, D. A. (1988). The psychology of everyday things (1st ed.). New York, NY: Basic Books, Perseus Books Group.

Ogunlesi, T. (2016, February 23). Inside Makoko: Danger and ingenuity in the world's biggest floating slum. The Guardian. Retrieved from http://www.theguardian.com

Paquet, G. (2013). Wicked policy problems and social learning. Optimum Online, 43(3). 
Rittel, H. W. J., \& Webber, M. (1973). Dilemmas in a general theory of planning. Policy Sciences, 4, 155-169. doi:10.1007/BF01405730

Schatzki, T. R. (2002). The site of the social: A philosophical account of the constitution of social life and change. Library. The Pennsylvania State University Press.

Sanders, E. B.-N., \& Stappers, P. J. (2014). From designing to co-designing to collective dreaming: Three slices in time. Interactions, 24-33.

The City of Portland Oregon Auditor's Office Archives and Records Management (2017, February 2). 188219 Amend Affordable Housing Preservation and Portland Renter Protections to add relocation assistance for involuntary displacements of tenants amend PCC 30.01.085 ordinance. Retrieved from efiles.portlandoregon.gov/record/10623592

Tonkinwise, C. (2015). Design for transitions from and to what? Design Philosophy Papers, 13(1), 85-92.

Tonkinwise, C. (2008). Knowing by being-there making: Explicating the tacit post-subject in use. Studies in Material Thinking, 1(2).

Willis, A.-M. (2015). Transition design: The need to refuse discipline and transcend instrumentalism. Design Philosophy Papers, 13(1), 69-74.

Young, I. M. (2003). Activist challenges to deliberative democracy. In J. S. Fishkin \& P. Laslett (Eds.), Debating deliberative democracy (Vol. 7, pp. 102-120). Oxford, UK: Blackwell Publishing Ltd.

Resumen: Históricamente, la educación de diseño se estructuró alrededor de proyectos como soluciones en un futuro previsible y cognoscible. Sin embargo, los investigadores que operan en el paisaje del Diseño para la Transición deben lidiar con un terreno mucho menos cierto. Los desafíos quedan fuera del alcance de lo que comúnmente se ha entendido como el ámbito del diseñador. Los proyectos de transición no encajan dentro de los ritmos habituales de los sistemas políticos, económicos y gubernamentales; a menudo requieren una coordinación completa y compleja entre los actores en diferentes sistemas; están dirigidos al cambio social, cultural y psicológico; la ubicación de la práctica es un sistema vivo que no ofrece un conjunto confiable de puntos de inflexión. Teniendo en cuenta la investigación de Diseño para la Transición basada en la práctica, este artículo describe los enfoques adoptados, analiza los desafíos de la realización de investigaciones y propone consideraciones clave para abordar en el trabajo futuro.

Palabras clave: Diseño para la transición, futuros, investigación basada en la práctica, economía alternativa

Resumo: Historicamente, a educação de design se estruturou ao redor de projetos como soluções num futuro previsível e cognoscível. Entretanto, os pesquisadores que operam na paisagem do Design para a Transição devem lutar com um território muito menos certo. Os desafios ficam fora do alcance do que comumente se denominou o âmbito do designer. Os projetos de transição não encaixam dentro dos ritmos habituais dos sistemas políticos, económicos e governamentais; com frequência requerem uma coordenação completa e 
complexa entre os atores em diferentes sistemas; estão dirigidos à mudança social, cultural e psicológica; a localização da prática é um sistema vivo que não oferece um sistema confiável de pontos de inflexão. Tendo em conta a pesquisa de Design para a Transição baseada na prática, este artigo descreve os enfoques adotados, analisa os desafios da realização de pesquisas e propõe considerações chave para abordar no trabalho futuro.

Palavras chave: Design para a Transição - futuros - pesquisa baseada na prática - economia alternativa. 